\title{
Selected Developments in Biotechnology Law and the Biotechnology Industry
}

\author{
By STEVEN J. ZWEIG
}

\section{CRISPR DEVELOPERS RECEIVE THE NOBEL PRIZE}

The 2020 Nobel Prize in Chemistry went to two researchers who developed the revolutionary CRISPR-Cas9 gene-editing tool. Jennifer A. Doudna (United States) and Emmanuelle Charpentier (France) developed CRISPR, which has been likened to "molecular scissors" for its ability to "cut" or "snip" genes exactly where wanted, allowing very precise edits to them. In recognizing the potential of CRISPR - "There is enormous power in this genetic tool," opined Claes Gustafsson, who chairs the Nobel Committee for Chemistry-the prize committee also recognized the power of biotechnology, which offers the possibility of treating inherited and formerly untreatable diseases.

\section{BIOTECH INDUSTRY PUSHES FOR STRICTER APPROVAL CRITERIA FOR COVID-19 VACCINES}

One usually assumes that industry trade groups want less or less-strict regulation. And that is certainly the case more often than not. But in the exception which proves the rule, BIO, the biotechnology industry trade group, wants the Food and Drug Administration (FDA) to promulgate stricter criteria for approving any COVID-19 vaccines. The FDA has in fact come up with stricter guidelines, but they have not been released as of writing, amidst the Trump administration's push to release a vaccine as soon as

Steven J. Zweig is the Managing Editor of Biotechnology Law Report. possible. While a large part of the administration's focus on an as-early-as-possible release was in the hope of getting an election boost-something which did not happen, as no vaccine candidates were even close to release by the election-even with the election out of the picture, President Trump is still committed to making a vaccine available quickly, since doing so in theory supports his goal of re-opening up the economy as fully as possible, as fast as possible.

We stress "in theory" because a vaccine is useless, no matter how efficacious it is in studies, if people don't take it. And right now, it's not looking good for mass vaccination in the U.S.: studies show that only $51 \%$ of Americans would take a COVID19 vaccine. Worse, that's down from $72 \%$ in May 2020: i.e., the populace's trust of a vaccine is waning fast, with the number willing to take the vaccine declining by almost one-third in just five months.

It's most likely waning because a vaccine has become politicized, just as mask-wearing or social distancing; with the administration pushing for early delivery of a vaccine to support its policies and agenda, people are becoming skeptical about whether it will be fully tested and safe. That's why BIO is in the anomalous position (for a trade group) of pushing for stricter, more stringent criteria: BIO wants to increase public confidence in the eventual vaccine(s).

As Dr. Michelle McMurry-Heath, BIO's president and CEO (and a former FDA official) stated recently, "We cannot allow a lack of transparency to undermine confidence in the vaccine development process. The public must have full faith in the scientific process and rigor of FDA's regulatory oversight if we are going to end the pandemic ... [A]ny sign that the White House-any White House-is interfering in the process will simply erode public confidence." 
Hence the biotech industry's push to hold them to a higher standard. Because to paraphrase an old saying, what if you had a vaccine and nobody came to take it?

\section{MOST COVID-19 VACCINES IN THE WORKS INVOLVE BIOTECHNOLOGY}

The New York Times has a "vaccine tracker" on the web which enables people to check on the status of the many COVID-19 vaccine candidates which are in the works. ${ }^{1}$

The Times breaks the vaccines into four categories:

- Genetic vaccines: vaccines which deliver one or more of the coronavirus's genes into the recipient's cells in order to stimulate an immune response;

- Viral vector vaccines: vaccines containing engineered viruses which contain coronavirus genes - the vaccines then cause the in-body production of coronavirus proteins, to cause an immune response;

- Protein-based vaccines: Vaccines containing coronavirus proteins (whole proteins or fragments thereof) but not coronavirus genes, and again use those proteins to invoke an immune response; and

- Inactivated or attenuated coronavirus vaccines: the most traditional type of vaccine of the four, using weakened or inactive ("killed") coronavirus to prompt an immune response-the viral particles are weakened or killed chemically.

Three of the above categories involve the use of what is commonly considered biotechnology: the genetic vaccines, the viral vector vaccines, and the protein-based vaccines. Since those three categories contain the vast bulk of vaccine candidates (on November 4, 2020, the Times listed 24 genetic vaccines, 24 viral vector vaccines, 63 proteinbased vaccines, but only 9 inactivated or attenuated coronavirus vaccines), it is evident that biotechnology is making a dramatic contribution to the fight against COVID-19.

You can see the status of specific vaccines by manufacturer using the New York Times tracker discussed above.

\section{BIDEN VS. TRUMP ON BIOTECHNOLOGY}

The Information Technology and Innovation Foundation (ITIF), a nonpartisan think tank, ${ }^{2}$ re- leased a report in September $2020^{3}$ comparing the U.S. presidential candidates' positions on a variety of scientific and technical areas-including biotechnology and life sciences.

As of writing (November 4, 2020), the U.S. presidential election is still up in the air, and given the need to count a wholly unprecedented number of mail-in ballots and the almost inevitable legal challenges, it may remain up on the air or subject to challenge for weeks to come. And, of course, once it is definitively resolved, the winner will have a great deal to say about the nation's biotechnology agenda.

The COVID-19 pandemic disguises some of the differences between them, since both would throw money at fighting the novel coronavirus (e.g., Trump's "Operation Warp Speed, which has committed over $\$ 10$ billion to the development of vaccines and therapeutics; Biden's call for a comprehensive national strategy including, among other things, vastly ramping up testing and funding the Biomedical Advanced Research and Development Authority adequately to produce vaccines and therapeutics). However, ITIF found, the pandemic emergency aside, there was a clear difference: Trump had not, pre-COVID-19, prioritized funding for the life sciences and biotechnology, while Biden has. That is in keeping with their general approach to technology: Biden favors more government involvement in and in support of many different technological areas, such as clean energy and universal broadband-as well as infrastructure and government investment generally, with Biden favoring using infrastructure investments to both pump money into an economy devasted by the pandemic and to increase American competitiveness, while Trump favors deregulation as a potential driver of private sector investment. In this, the candidates to a large degree stake out traditional Republican and Democratic (or conservative and liberal) positions.

\footnotetext{
${ }^{1}$ Jonathan Corum, Sui-Lee Wee, and Carl Zimmer, Coronavirus Vaccine Tracker, N.Y. Times, https://www .nytimes.com/interactive/2020/science/coronavirus-vaccinetracker.html

${ }^{2}$ Information Technology and Innovation Foundation, WIKIPEDIA, https://en.wikipedia.org/wiki/Information Technology_and_Innovation_Foundation
} 